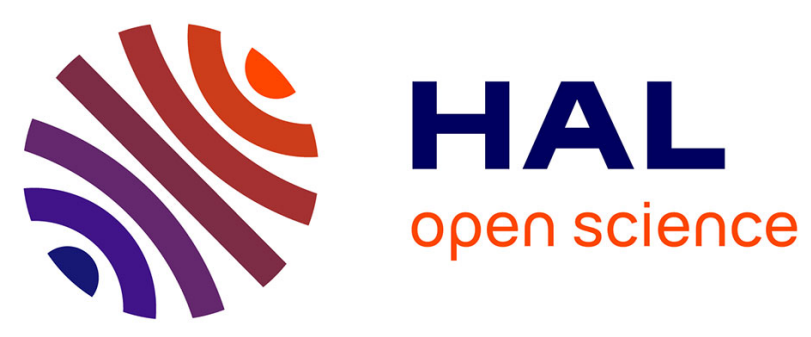

\title{
Does a strong pycnocline impact organic-matter preservation and accumulation in an anoxic setting? The case of the Orca Basin, Gulf of Mexico
}

Nicolas Tribovillard, Viviane Bout-roumazeilles, Thomas Sionneau, Montero Serrano, Armelle Riboulleau, François Baudin

\section{To cite this version:}

Nicolas Tribovillard, Viviane Bout-roumazeilles, Thomas Sionneau, Montero Serrano, Armelle Riboulleau, et al.. Does a strong pycnocline impact organic-matter preservation and accumulation in an anoxic setting? The case of the Orca Basin, Gulf of Mexico. Comptes Rendus. Géoscience, 2009, 341 (1), pp.1-9. 10.1016/j.crte.2008.10.002 . hal-03327498

\section{HAL Id: hal-03327498 \\ https://hal.science/hal-03327498}

Submitted on 27 Aug 2021

HAL is a multi-disciplinary open access archive for the deposit and dissemination of scientific research documents, whether they are published or not. The documents may come from teaching and research institutions in France or abroad, or from public or private research centers.
L'archive ouverte pluridisciplinaire HAL, est destinée au dépôt et à la diffusion de documents scientifiques de niveau recherche, publiés ou non, émanant des établissements d'enseignement et de recherche français ou étrangers, des laboratoires publics ou privés. 
Does a strong pycnocline impact organic-matter preservation and accumulation in an anoxic setting? The case of the Orca Basin, Gulf of Mexico

Nicolas Tribovillard a,*, Viviane Bout-Roumazeilles a , Thomas Sionneau a, Jean Carlos Montero Serrano ${ }^{\text {a }}$, Armelle Riboulleau ${ }^{\text {a }}$, François Baudin ${ }^{\mathrm{b}}$

${ }^{a}$ UMR 8110 CNRS Géosystèmes, UFR des Sciences de la Terre, université Lille-1, bâtiment SN5, 59655 Villeneuve d'Ascq cedex, France

${ }^{\mathrm{b}}$ Département de géologie sédimentaire, UMR 7072 CNRS Tectonique, université Paris-6, 4, place Jussieu, 75252 Paris cedex 05, France

*Corresponding author. E-mail address: Nicolas.Tribovillard@univ-lille1.fr (N. Tribovillard).

\begin{abstract}
The Orca Basin (an intraslope depression located in the Gulf of Mexico) collects sedimentary particles of terrestrial origin (clastic and organic particles mainly supplied by the Mississippi River) and of marine origin (biogenic productivity). The basin is partly filled with dense brines leached from salt diapirs cropping out on the sea floor, and is permanently stratified. A strong pycnocline induces anoxic bottom conditions, expectedly favorable to organic matter $(\mathrm{OM})$ preservation. Here, we report on $\mathrm{OM}$ in the upper $750 \mathrm{~cm}$ below sea floor of Core MD02-2552 (Holocene). The organic content is dominated by marine-derived amorphous OM. The organic assemblage is unexpectedly degraded to some extent, which may be accounted for by a relatively long residence time of organic particles at the haloclinepycnocline at $! 2240 \mathrm{~m}$. Thus the organic particles are temporarily trapped and kept in contact with the dissolved oxygen-rich overlying water mass. Lastly, the land-derived organic fraction shows co-variations with the land-derived clay mineral supply.
\end{abstract}

Résumé

Une pycnocline concentrée a-t-elle un impact sur la préservation de la matière organique et sur son accumulation dans un dépôt anoxique ? Le bassin d'Orca, petite dépression située dans le Golfe du Mexique, reçoit des particules sédimentaires d'origine continentale (clastiques et organiques), véhiculées par le Mississippi principalement, et d'origine marine (productivité). Le bassin est partiellement rempli par des saumures issues du lessivage de diapirs salifères affleurant dans les fonds marins. La colonne d'eau y est très fortement stratifiée et le corps d'eau situé sous la halocline-pycnocline est totalement 
anoxique. Cette anoxie est a priori favorable à la préservation de la matière organique (MO). Nous étudions ici le contenu organique des premiers $750 \mathrm{~cm}$ de la carotte MD02-2552 déposés au cours de l'Holocène. Le contenu organique est dominé par la MO amorphe d'origine marine. L'état de préservation de la MO est étonnamment mauvais, compte tenu du contexte de dépôt. Cela est dû au fait que la MO est retenue durablement à l'interface de densité à $2240 \mathrm{~m}$ de profondeur, ce qui permet un long séjour dans des conditions encore relativement riches en oxygène dissous. Enfin, les particules organiques terrigènes montrent une distribution relativement bien corrélée à celle des minéraux argileux.

Keywords: Holocene; Anoxia; Organic matter preservation; Palynofacies; Clay minerals

Mots clés : Holocène ; Anoxie ; Préservation de la matière organique ; Palynofaciès ; Minéraux argileux

\section{Introduction}

Organic matter (OM) storage in marine sediments is an important step of the carbon cycle on geological time scales. Usually, the main factors conditioning OM concern the origin of organic products, and their conditions of productivity, transfer to the sediments and diagenesis (see extensive reviews in [16,25,26], and references therein). In this paper, we report on the sources, quantity and preservation state of $\mathrm{OM}$ of recent, mostly Holocene, sediments of the Orca Basin (Fig. 1A et B). Located within the Gulf of Mexico, the Orca Basin is a small depression characterized by the presence of very dense bottom brines, separated from the above water mass by a marked pycnocline or halocline (Fig. 1C). The stratified bottom water mass causes the development of anoxic bottom conditions that can potentially favor organic matter preservation. Our aims are to discriminate land derived and autochthonous fractions of the sedimentary $\mathrm{OM}$ and to account for the preservation state of $\mathrm{OM}$ that results from two antagonist factors: the anoxic bottom waters must favor $\mathrm{OM}$ preservation but the extreme density contrast separating bottom brines from the overlying oxygenated water mass forces OM to lie durably at the pycnocline where it may undergo extensive degradation.

\section{The Orca Basin, a short description}

The Orca Basin is characterized by strong water column stratification (Fig. 1C) $[17,24]$. The 400-km2 elbow-shaped depression results from regional salt tectonics along the Louisiana continental slope. The basin water depths range from about 1800 to $2400 \mathrm{~m}$ in the 
deepest parts (Fig. 1B). The bottom $200 \mathrm{~m}$ of the Orca Basin are permanently anoxic $[7,18,27]$ and salinity is kept above $260 \mathrm{~g} / 1$ due to the dissolution of shallow subsurface salt diapirs [19], whereas the overlying seawater has a salinity of $35 \mathrm{~g} / \mathrm{l}$. The resulting density contrast at the seawater-brine interface induces a strong stratification of the water column ([24] and references therein). A considerable part of the particulate flux settling into the basin is trapped at the pycnocline region (2200-2250 m; [17]) and the retained particules consist of up to $60 \%$ OM $[22,27]$. Wong et al. [29] and Sheu [17] reported that the settling OM is trapped at the stable pycnocline long enough to undergo a detectable degradation that is reflected by the strong release of biogenic iodine at the density interface. Addy and Behrens [1] dated the beginning of anoxia around 8000 years BP but Presley and Stearns [11] proposed that anoxia have existed for at least 50,000 years.

The Orca Basin collects an important land-derived fraction consisting of terrigenous clastic and OM from the Mississippi River. The Mississippi River is by far the largest sediment source to the Gulf of Mexico. The tributary contributing most to overall runoff is the Ohio River, reflecting the higher precipitation in the eastern part of the Mississippi catchments. Most of the sediment load, however, is derived from the Missouri River catchments [20].

\section{Material and methods}

We sampled core MD02-2552 collected during the 2002 cruise of the R/V MarionDufresne. The core location is: latitude $26856.80 \mathrm{~N}$, longitude $91820.72 \mathrm{~W}$, maximum water depth $2240 \mathrm{~m}$. The sediments consist entirely of black microlaminated (mm- to $\mathrm{cm}$-scale) mud (silty clay). Seventy-five sediment samples were taken every $10 \mathrm{~cm}$ through the upper $7.5 \mathrm{~m}$ of the core. Only one age datum is available for the studied interval: the sample at 540 $\mathrm{cm}$ below sea floor (cmbsf) is dated by $14 \mathrm{C}$ at $9838 \mathrm{yr}$ cal BP [20]. The next available 14C age datum downcore is at $790 \mathrm{cmbsf}$ and is $13,500 \mathrm{yr}$ cal BP. If we extrapolate an age for the base of the sampled interval, the deepest sample would be dated of 12,700 yr cal BP [24].

Usual Rock-Eval pyrolysis parameters, namely, total organic carbon content (TOC, wt $\%)$, Tmax (8C), and Hydrogen Index (HI, in mg hydrocarbon per g TOC) were determined with a Delsi Oil Show Analyser (Rock Eval II). The pyrolyse cycle was adapted to recent sediments (see [6] for procedural details and [5] for Rock Eval use for Holocene sediments). The trace metal and carbonate contents, Rock-Eval and grain-size parameters were published in [24]. Standard palynological techniques [8] were used to prepare total untreated kerogen slides from the residues of $\mathrm{HCl}$ and $\mathrm{HF}$ digestion. The nature of the palynofacies assemblages 
was determined by analyzing 300 points per slide. Following [25], several particle categories were discriminated: plankton-derived amorphous organic matter (AOM), and the so-called "figured elements" (i.e., the nature/origin of which can be identified): phytoclasts, spores and pollen, marine algae, and zooplankton debris. The phytoclasts were subdivided into:

- black opaque particles, i.e., biochemically oxidized wood debris;

- $\quad$ structured brown phytoclasts, i.e., cortex and secondary xylem;

- leaf and membranous tissues, i.e., cuticles and epidermal tissues.

The black opaque particles may reflect several possible origins: combustion residue (i.e., soot and charcoal), or deeply oxidized phytoclasts created by repeated cycles of degradation, or a woody particles altered by thermal maturation (i.e., coalfield material) and inherited from the geological substratum $[16,25]$. The phytoclast categories were based primarily on translucency, particle shape, and the presence or absence of botanical microstructure. The qualitative six-point fluorescence scale of Tyson [25] was used to estimate the level of preservation of OM.

The clay mineral data used here are from [20] and the composition of clay mineral assemblage was determined following [3].

\section{Results}

\subsection{Palynofacies}

The palynofacies are dominated by a brown-colored amorphous OM (AOM) that is characterized by a heterogeneous "floc" structure and "fuzzy" outlines, and shows a relatively granular texture (Fig. 2). This AOM also shows a hardly-detectable fluorescence. In all the observed slides, AOM represents more than $80 \%$ of the OM visible on slide surface. This kind of brown AOM is of marine origin, deriving from bacterial, algal and planktonic sources $[13,16,25]$. Several studies indicated that this type of brown AOM is nonsulfurized whereas organic S-rich OM appears as orange-colored AOM - not observed here (see descriptions in $[8,9,12,23])$. The observed AOM particles show a relatively small surface area and a sort of brittle aspect, relative to what is commonly observed on this type of AOM.

In addition to AOM, figured organic elements are observed. To determine the respective proportions of phytoclasts and palynomorphs in the study units, we used a particle counting procedure that ignored AOM. The stratigraphic distribution of the figured components of the palynofacies is illustrated in Fig. 3. The figured elements are dominated by brown phytoclasts, opaque debris, and marine algae, ranked in order of decreasing abundance. 
Present in small quantities are zoomorph remains, leaf and membranous tissues, as well as spores and pollen grains. From the base of the core to $200 \mathrm{cmbsf}$, the abundance of opaque debris decreases progressively (with some minor increases however at ca 270 and $230 \mathrm{cmbs}$ ); the abundance of marine algae remains rather constant $(10-20 \%$ of the non-amorphous fraction). A peculiar level is observed at $200 \mathrm{cmbsf}$ marked by a minimum in the abundance of opaque debris and a sharp decrease in the abundance of marine algae. Above $200 \mathrm{cmbsf}$, the abundance of opaque debris increases progressively, while the abundance of marine algae remains low $(<10 \%)$. The 200 -cmbsf level is also characterized by a peak in zoomorph remains.

The interval between 280 and $380 \mathrm{cmbsf}$ corresponds to a transition zone within which the abundance of brown phytoclasts decreases substantially, from concentrations of 45 to $65 \%$ below $380 \mathrm{cmbsf}$ to concentrations mainly comprised between 30 and $50 \%$ above $280 \mathrm{cmbsf}$. The horizon at about $340 \mathrm{cmbsf}$ corresponds to the end of a steadily-decreasing vertical trend in opaque debris, and the beginning of an increasing-upward sequence (which shows some initial instabilities). The distributions of the other types of figured elements show no relationship with the on going of this horizon.

\subsection{Rock Eval parameters}

In general, the three parameters, namely, TOC; HI and Tmax, show little variation (Fig. 3). A slight increase in TOC and HI is observed from the base of the section upward, followed by a small decrease at the top (Fig. 3). Tmax values show a smooth distribution with a faint general decrease upward (Fig. 3). As indicated by a Tmax vs HI diagram (Fig. 4), the studied core contains an immature mixture of type-II and type-III OM, i.e., of marine and terrestrial OM. A rough tendency may be observed between TOC and HI (Fig. 4), and the four samples that are the richest in OM (TOC $>1 \%$ ) do not show the highest HI values. A rather poor correlation is suggested in a Tmax vs HI crossplot (Fig. 4) in which the highest Tmax values are associated with the lowest HI value. Noticeably, no relationship can be observed between Rock Eval parameters and the palynofacies constituents.

\subsection{Comparison with the clay-mineral content}

The vertical distribution of the land-derived organic figured elements can be compared to that of the clay minerals, which are delivered to the Orca Basin mostly by the Mississippi River. The clay-mineral data reported here are from Sionneau et al. [20 and references therein]. The most salient feature observed is the rather good covariation between the 
concentrations of opaque debris and the ratio of chlorite to kaolinite (Fig. 5A). For both parameters, a decreasing trend is observed from the base of the section to $350 \mathrm{cmbsf}$, then an interval of strong covariation is observed from $350 \mathrm{cmbsf}$ to $200 \mathrm{cmbsf}$. The correlation between opaque debris and the chlorite/kaolinite ratio is less strong for the upper $200 \mathrm{~cm}$ of the core, despite a general upward increase in both parameters. However, for the upper 200 $\mathrm{cm}$, a peak-to-peak correspondence is observed between the chlorite/kaolinite ratio and the sum of the abundances of all terrigenous figured elements (Fig. 5B). No other significant relationship was observed between clay minerals and palynofacies constituents (brown phytoclasts, sporomorphs, and marine palynomorphs).

\section{Interpretations}

\subsection{OM preservation}

The whole data set shows moderate HI values (100- $200 \mathrm{mg}$ hydrocarbon per g TOC) for a recent organic content overwhelmed by marine-origin AOM, whereas higher values would have been expected for Holocene deposited under anoxic conditions [5]. This observation indicates that $\mathrm{OM}$ could be relatively degraded all along the studied part of the core. The quasi-absence of fluorescence of the AOM confirms this interpretation.

The stratigraphic distribution of the Rock Eval parameters is not impacted by the variations in the abundance of the various types of figured organic elements, despite the contrasting chemical composition of these elements that should affect both Tmax and HI parameters. This observation suggests that the dominating presence of marine AOM mutes the chemical impact of the variations of figured elements. In this view, the decrease in TOC and HI with depth can be attributed to a progressive degradation of OM.

The small size of brown AOM particles and their brittle aspect indicate a relatively poor preservation state. The figured elements are dominated by brown and black phytoclasts that are refractory constituents, and correlatively poor in more labile constituents such as leaf cuticles or epidermis. This selective enrichment in the more resistant figured elements is unexpected for a depositional setting that is close to the Mississippi River mouth, suggesting that $\mathrm{OM}$ underwent some degradation that removed most of the more labile fraction of the figured elements [14].

Consequently, our results indicate that the organic assemblage underwent some degradation; however the bottom sea water and porewaters in the Orca Basin are strictly anoxic and one would expect OM preservation to be favored under such conditions (of course other factors are involved in OM preservation; see e.g., [26] for a recent review). At least, one 
would expect AOM to show some fluorescence, which is not the case. The release of appreciable amounts of biogenic iodine at the pycnocline was observed, inducing that settling $\mathrm{OM}$ is trapped at the stable pycnocline long enough to undergo extensive degradation [17,29]. No published data allow estimating this residence time at the pycnocline. The effect of degradation that we independently observe on the organic assemblage is consistent with the results of these authors. The strong density contrast affecting the water column would retain the settling $\mathrm{OM}$ at the pycnocline for some time. At the pycnocline, OM would remain in contact with the overlying oxygen-rich water mass. The contact would last long enough to favor OM degradation, which may explain the relatively poor preservation of AOM and the selective enrichment in the more refractory fraction of the figured elements.

The relative degradation of $\mathrm{OM}$ could at least partly explain why the rate of bacterially-mediated sulfate reduction is rather low in the Orca Basin. The low rate was already reported, despite abundant dissolved sulfate and appreciable OM [17,22]. According to the study by Porter et al. [10], high salinity cannot be suspected as the cause of lower sulfate reduction rates. Consequently, it is suggested that relatively degraded OM could not sustain extensive sulfate reduction.

\subsection{Influence of the land-derived supply}

Our study of the palynofacies assemblage and of its co-variations with the claymineral spectrum reveals the significant inputs of land-derived OM to the Orca Basin, though the marine-produced organic fraction is dominant. A prominent feature in the stratigraphic distribution of the figured elements is the covariation of the opaque debris and clay minerals (Fig. 5). The main source of the land-derived clay minerals deposited in the Orca Basin is the Mississippi River catchment. Clay minerals originating from the weathering of continental source rocks are formed on a time scale of about 500,000 yrs [4,21], that is, on a time scale much longer than the age of the sediments studied here. Because the studied sediments are of Holocene age, variations in the clay mineral composition must therefore reflect different source regions over the very large river catchment rather than climate-induced evolution of constant sources. Consequently, the correlation between the terrigenous constituents of the palynofacies and the land-derived clay mineral assemblage indicates that the variations affecting palynofacies must be ascribed to fluctuations of the land-derived inputs and not to variations of the OM-preservation conditions. The Mississippi River catchment may be divided into various areas that are each characterized by their peculiar clay mineral assemblage [20]. It is inferred that the composition of the clay-mineral assemblage of the 
sediments of the Orca Basin may be influenced by the way the Mississippi River catchment undergoes erosion. According to the main areas of the catchment (and consequently the inventories of clay minerals) that are subjected to erosion, the dominant clay minerals delivered to the Gulf of Mexico, and thus the Orca Basin, will change with time in conjunction with the remobilized inventory of organic particles. Thus, our results suggest that further studies could help to determine the modalities of erosion of a large part of the North American continent through the Holocene.

\section{Conclusions}

Though the anoxic bottom conditions should favor preservation, OM is rather degraded in the Orca Basin sediments and its degradation must be accounted for, at least in part, by extended residence of the OM particles at the stable brine-sea water interface at 2230-2250 m water depth, where OM is subjected to oxic conditions. The degradation deduced from the release of abundant biogenic iodine at the pycnocline is confirmed by the relatively low HI values, the low fluorescence of the kerogens found within the sediment at all levels, including at the sediment-water interface, and the visual aspect of AOM. Usually, OM preservation and accumulation are reputed to depend on several factors including: productivity, magnitude of sedimentation rate, oxygenation level/redox status of bottom and pore waters, biochemical nature of OM. Several works also stressed the influence of remineralization processes occurring during organic-particle settling through the water column (e.g., [2,28], and references therein). The present study shows that OM may be degraded within the water column when it is retained durably at the pycnocline. Thus, high productivity coupled to strictly anoxic conditions cannot guarantee significant $\mathrm{OM}$ accumulation if a marked pycnocline strongly slows down organic-particle settling. Our results may apply to any basin characterized by a sharp density contrast within its mater mass.

This study also illustrates that a relative variability may be detected within the flux of land-derived organic particles whereas this variability does not correspond to major or even moderate fluctuations of hydrological conditions in the Gulf of Mexico or global climate affecting the emerged lands drained by the Mississippi River (almost half of the conterminous United States). The modest (regional scale) variations in Holocene climatic conditions (reputedly largely equable) on emerged lands can - in fact - induce appreciable variations in the sedimentary organic record. These observations must be kept in mind while studying ancient geological series: one is exposed to "overinterpreting" mineralogical variations when reconstructing paleoenvironments at the geological scale. 


\section{Acknowledgements}

We thank Yvon Balut, the Institut Paul-Emile Victor (IPEV), the crew of the MarionDufresne $\mathrm{R} / \mathrm{V}$ and the IMAGES and Page programs for core collection. We thank the technical staff of the Géosystèmes lab: Léa- Marie Emaille, Laurence Debeauvais, Deny Malengros and Philippe Recourt. Thanks to the two anonymous referees for their constructive reviews, and to Michel Petit for his editorial work. Thanks to Jean-Robert Disnar for his kind help, constant through time.

\section{References}

[1] S.K. Addy, E.W. Behrens, Time of accumulation of hypersaline anoxic brine in Orca basin (Gulf of Mexico), Mar. Geol. 37 (1980) 241-252.

[2] T.S. Arnarson, R.G. Keil, Changes in organic matter-mineral interactions for marine sediments with varying oxygen exposure times, Geochim. Cosmochim. Acta 71 (2007) 35453556.

[3] V. Bout-Roumazeilles, E. Cortijo, L. Labeyrie, P. Debrabant, Clay mineral evidence of nepheloid layer contribution to the Heinrich layers in the Northwest Atlantic, Palaeogeogr., Palaeoclimatol., Palaeocol. 146 (1999) 211-228.

[4] H. Chamley, Clay Sedimentology, Springer, Berlin, 1989, 623 p.

[5] J.-R. Disnar, J. Jacob, M. Morched-Issa, N. Lottier, F. Arnaud, Assessment of peat quality by molecular and bulk geochemical analysis: Application to the Holocene record of the Chautagne marsh (Haute Savoie, France), Chem. Geol. 254 (2008) 101- 112.

[6] J. Espitalié, G. Deroo, F. Marquis, La pyrolyse Rock Eval et ses applications, Part B, Rev. Inst. Franç. Pétr. 40 (1986) 755-784.

[7] M.T. Hurtgen, T.W. Lyons, E.D. Ingall, A.M. Cruse, Anomalous enrichments of iron monosulfide in euxinic marine sediments and the role of $\mathrm{H} 2 \mathrm{~S}$ in iron sulfide transformations: examples from Effingham Inlet, Orca Basin, and the Black Sea, Am. J. Sci. 299 (1999) 556588.

[8] E. Lallier-Vergès, J. Hayes, N. Tribovillard, D. Zaback, J. Connan, P. Bertrand, Productivity induced cyclic sulfur enrichment of hydrocarbon-rich sediments from the Kimmeridge Clay Formation, Chem. Geol. 134 (1972) 77-288.

[9] T. Mongenot, M. Boussafir, S. Derenne, E. Lallier-Vergès, C. Largeau, N. Tribovillard, Sulphur-rich organic matter from Bituminous Laminites of Orbagnoux (France, Upper Kimmeridgian) - the role of early vulcanization, Bull. Soc. Geol. France 168 (1997) 331-341. 
[10] D. Porter, A.N. Roychoudhury, D. Cowan, Dissimilatory Sulfate Reduction in Hypersaline Coastal Pans: Activity Across a Salinity Gradient, Geochim. Cosmochim. Acta 71 (2007) 5102-5116.

[11] B. J. Presley, S. Stearns, Interstitial water chemistry, Deep Sea Drilling Project Leg 961, In: Bouma, A. H., Coleman, J. M., Meyer, A. W., et al., Init. Repts. DSDP, 96, US Govt. Printing Office, Washington, 1986, pp. 697-709.

[12] A. Riboulleau, F. Baudin, J.-F. Deconninck, S. Derenne, C. Largeau, N. Tribovillard, Depositional conditions and organic matter preservation pathways in an epicontinental environment: the Upper Jurassic Kashpir Oil Shales (Volga Basin, Russia), Palaeogeogr., Palaeoclimatol., Palaeoecol. 197 (2003) 171- 197.

[13] L. Roncaglia, A. Kujper, Revision of the palynofacies model of Tyson (1993) based on recent high-latitude sediments from the North Atlantic, Facies (2005). DOI 10.1007/s10347005-0028-y.

[14] T.P. Sampere, T.S. Bianchi, S.G. Wakeham, M.A. Allison, Sources of organic matter in surface sediments of the Louisiana Continental margin: Effects of major depositional/transport pathways and Hurricane Ivan, Cont. Shelf Res. 28 (2008) 2472-2487.

[15] J. Schijf, Alkali elements ( $\mathrm{Na}, \mathrm{K}, \mathrm{Rb})$ and alkaline earth elements ( $\mathrm{Mg}, \mathrm{Ca}, \mathrm{Sr}, \mathrm{Ba})$ in the anoxic brine of Orca Basin, northern Gulf of Mexico, Chem. Geol. 243 (2007) 255-274.

[16] D. Sebag, Y. Copard, Ch. Di-Giovanni, A. Durand, B. Laignel, S. Ogier, E. LallierVerges, Palynofacies as useful tool to study origins and transfers of particulate organic matter in recent terrestrial environments: Synopsis and prospects, Earth-Sci. Rev. 79 (2006) 241259.

[17] D.-D. Sheu, The anoxic Orca Basin (Gulf of Mexico): Geochemistry of brines and sediments, Rev. Aquat. Sci. 2 (1990) 491-507.

[18] D.-D. Sheu, B.J. Presley, Variations of calcium carbonate, organic carbon and iron sulfides in anoxic sediment from the Orca Basin, northern Gulf of Mexico, Mar. Geol. 70 (1986) 103-118.

[19] D.-D. Sheu, A. Shakur, J.D. Pigott, D.A. Wiesenburg, J.M. Brooks, H.R. Krouse, Sulfur and oxygen isotopic compositions of dissolved sulfate in the Orca Basin: implications for origin of the high-salinity brine and oxidation of sulfides at the brine seawater interface, Mar. Geol. 78 (1987) 303-310.

[20] T. Sionneau, V. Bout-Roumazeilles, P.E. Biscaye, B. van Vliet- Lanoë, A. Bory, Clay mineral distributions in and around the Mississippi River watershed and Northern Gulf of Mexico: sources and transport patterns, Quaternary Sci. Rev. 27 (2008) 1740-51. 
[21] M. Thiry, Palaeoclimatic interpretation of clay minerals in marine deposits: an outlook from the continental origin, Earth-Sci. Rev. 49 (2000) 201-221.

[22] J.H. Trefry, B.J. Presley, W.L. Keeney-Kennicutt, R.P. Trocine, Distribution and chemistry of manganese, iron, and suspended particulates in Orca Basin, Geo-Mar. Let. 4 (1984) 125-130.

[23] N. Tribovillard, A. Bialkowski, R.V. Tyson, E. Vergès, J.-F. Deconninck, Organic facies and sea level variation in the Late Kimmeridgian of the Boulonnais area northernmost France, Mar. Petrol. Geol. 18 (2001) 371-389.

[24] N. Tribovillard, V. Bout-Roumazeilles, T.J. Algeo, T.W. Lyons, T. Sionneau, J.C. Montero-Serrano, A. Riboulleau, F. Baudin, Paleodepositional conditions in the Orca Basin as inferred from organic matter and trace metal contents, Mar. Geol. 254 (2008) 62-72.

[25] R.V. Tyson, Sedimentary organic matter: organic facies and palynofacies, Chapman \& Hall, London, 1995, p. 615.

[26] R.V. Tyson, The "productivity versus preservation'" controversy: cause, flaws, and resolution, In: Harris, N. (Ed.), The Deposition of Organic-Carbon-Rich Sediments: Models, Mechanisms, and Consequences, SEPM Special Publication No. 82, 2005, pp. 17-33.

[27] P. Van Cappellen, E. Viollier, A. Roychoudhury, L. Clark, E. Ingall, K. Lowe, T. DiChristina, Biogeochemical cycles of manganese and iron at the oxic-anoxic transition of a stratified marine basin (Orca Basin, Gulf of Mexico), Environ. Sci. Techn. 32 (1998) 29312939.

[28] K.Wallmann, G. Aloisi, M. Haeckel, A. Obzhirov, G. Pavlova, P. Tishchenko, Kinetics of organic matter degradation, microbial methane generation, and gas hydrate formation in anoxic marine sediments, Geochim. Cosmochim. Acta 70 (2006) 3905-4392.

[29] G.T.F. Wong, K. Takayanagi, J.F. Todd, Dissolved iodine in waters overlying and in the Orca Basin, Gulf of Mexico, Mar. Chem. 17 (1985) 177-183. 


\section{Figure captions}
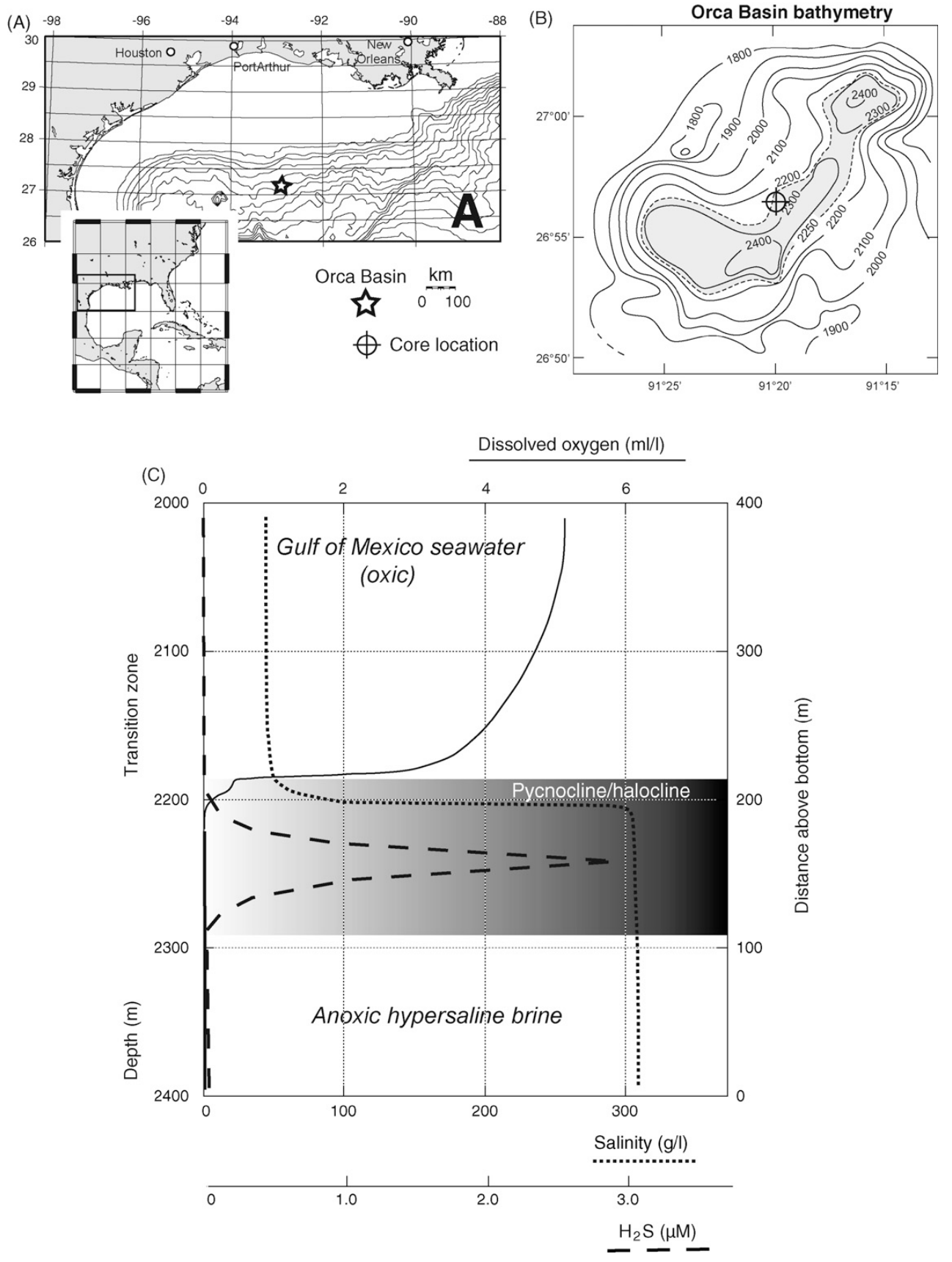

Fig. 1. Location (A) and bathymetry (B) of the Orca Basin in the Gulf of Mexico. The general maps were drawn using the online map creation device at the following website: http://www.aquarius.ifm-geomar.de/. The bathymetry map is redrawn from [24]. Contours in meters. C. Depth profiles of dissolved oxygen, dissolved $\mathrm{H}_{2} \mathrm{~S}$ and conductive salinity in the Orca Basin (redrawn from [15,18]).

Fig. 1. Localisation (A) et bathymétrie (B) du Bassin d'Orca dans le Golfe du Mexique. Les cartes ont été dessinées grâce au site : http:// www.aquarius.ifm-geomar.de/. La bathymétrie est redessinée d'après [24]. Les profondeurs sont en mètres. C. Distribution verticale des teneurs en $\mathrm{O}_{2}$ et $\mathrm{H}_{2} \mathrm{~S}$ et de la salinité dans le Bassin d'Orca (d'après [15,18]). 


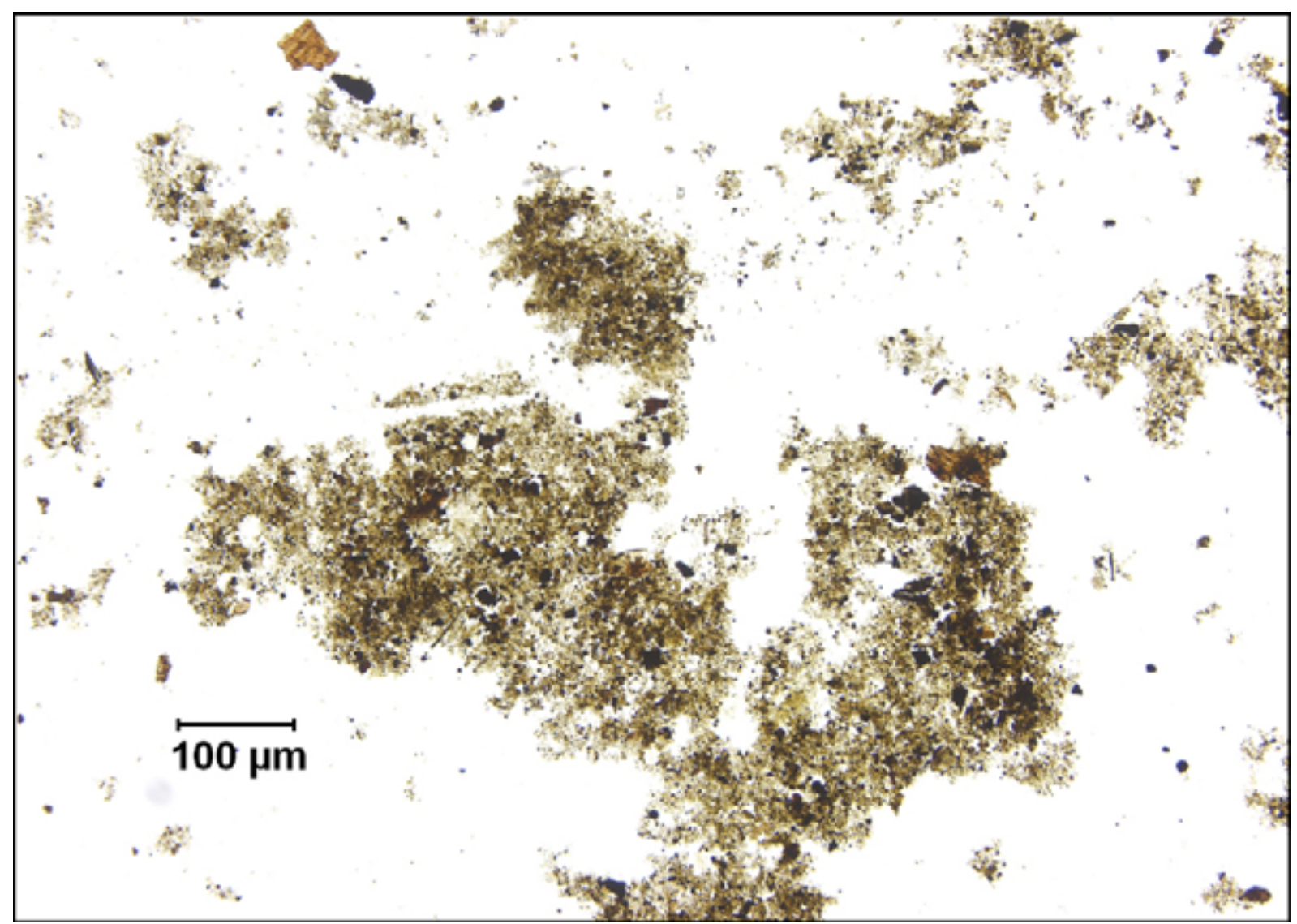

Fig. 2. Microphotographs showing the amorphous OM that dominates the palynofacies.

Fig. 2. Microphotographies illustrant la matière organique amorphe rencontrée dans les sédiments étudiés 


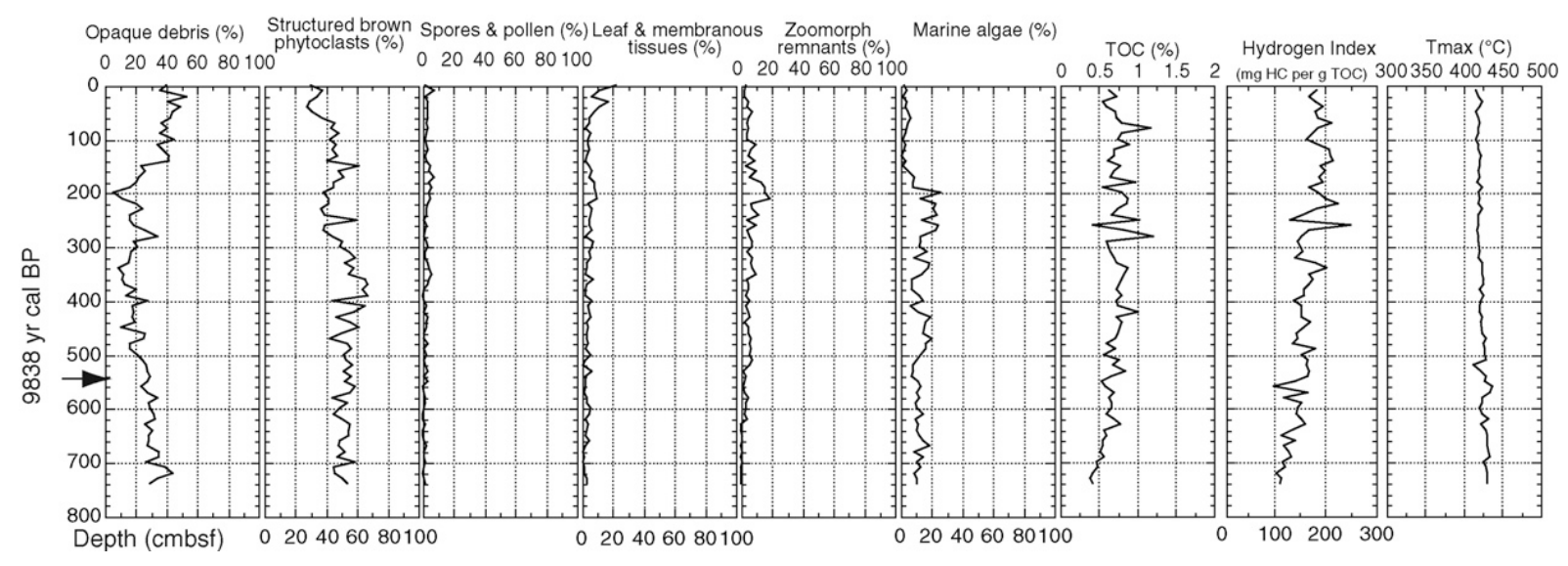

Fig. 3. Stratigraphic distribution of the various types of figured elements of the palynofacies, of three classical Rock Eval pyrolysis parameters (total organic carbon or TOC; Hydrogen Index; Tmax).

Fig. 3. Distribution verticale des différents types d'éléments figurés observés dans les palynofaciès et des paramètres classiques de la pyrolyse Rock Eval (carbone organique total ou TOC, indice d'hydrogène ou HI, Tmax). 

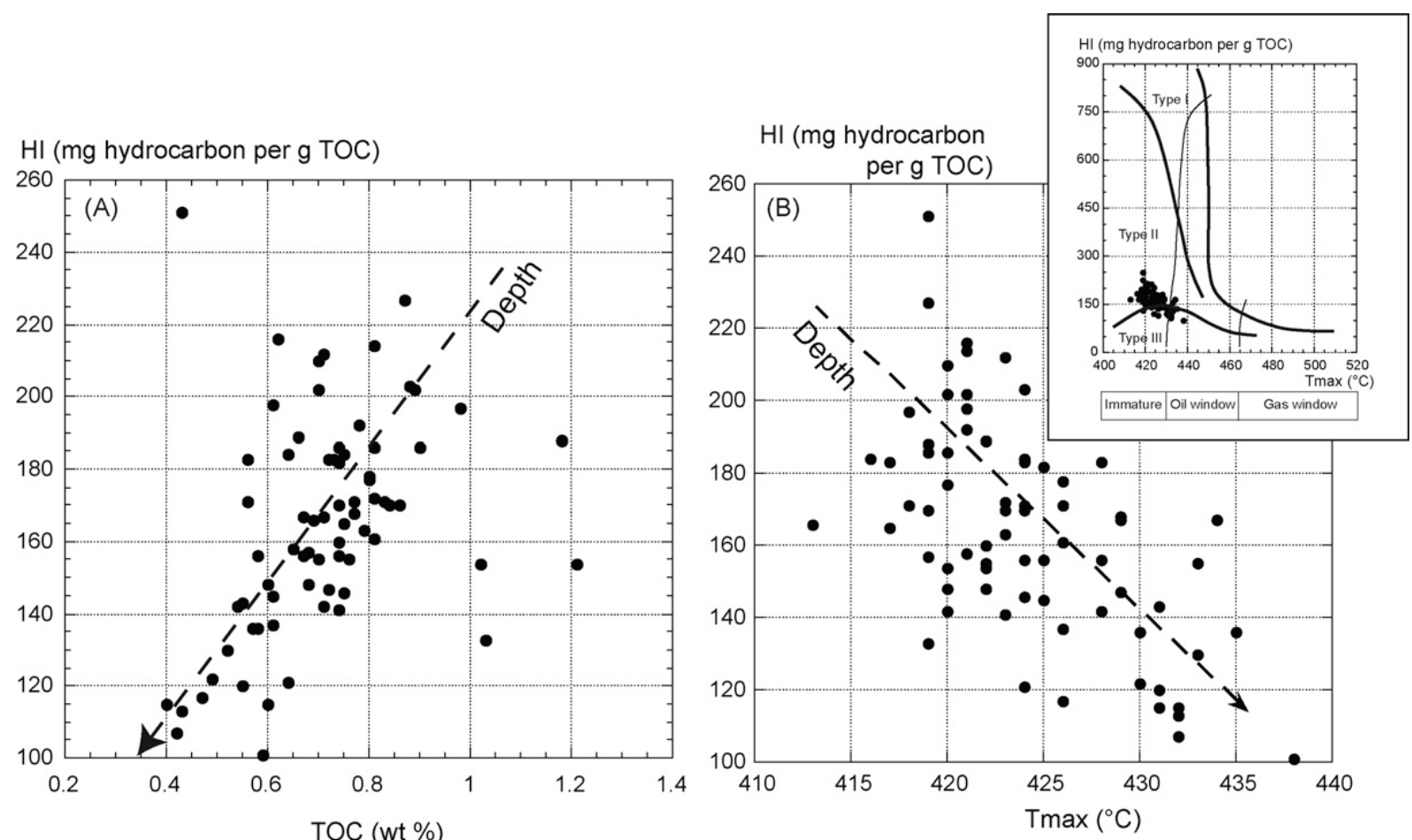

Fig. 4. Rock Eval pyrolysis parameters. A. TOC vs Hydrogen Index (HI). B. Tmax vs HI crossplot illustrating the origin and maturation state of the samples. The arrows on A and B show the general tendency with sample depth below sea floor.

Fig. 4. Paramètres de la pyrolyse Rock Eval. A. Diagramme TOC vs HI. B. Diagramme Tmax vs HI permettant d'illustrer la nature et le degré de maturation de la matière organique. Les flèches en $\mathrm{A}$ et $\mathrm{B}$ illustrent la tendance générale de l'évolution des paramètres avec la profondeur des échantillons. 

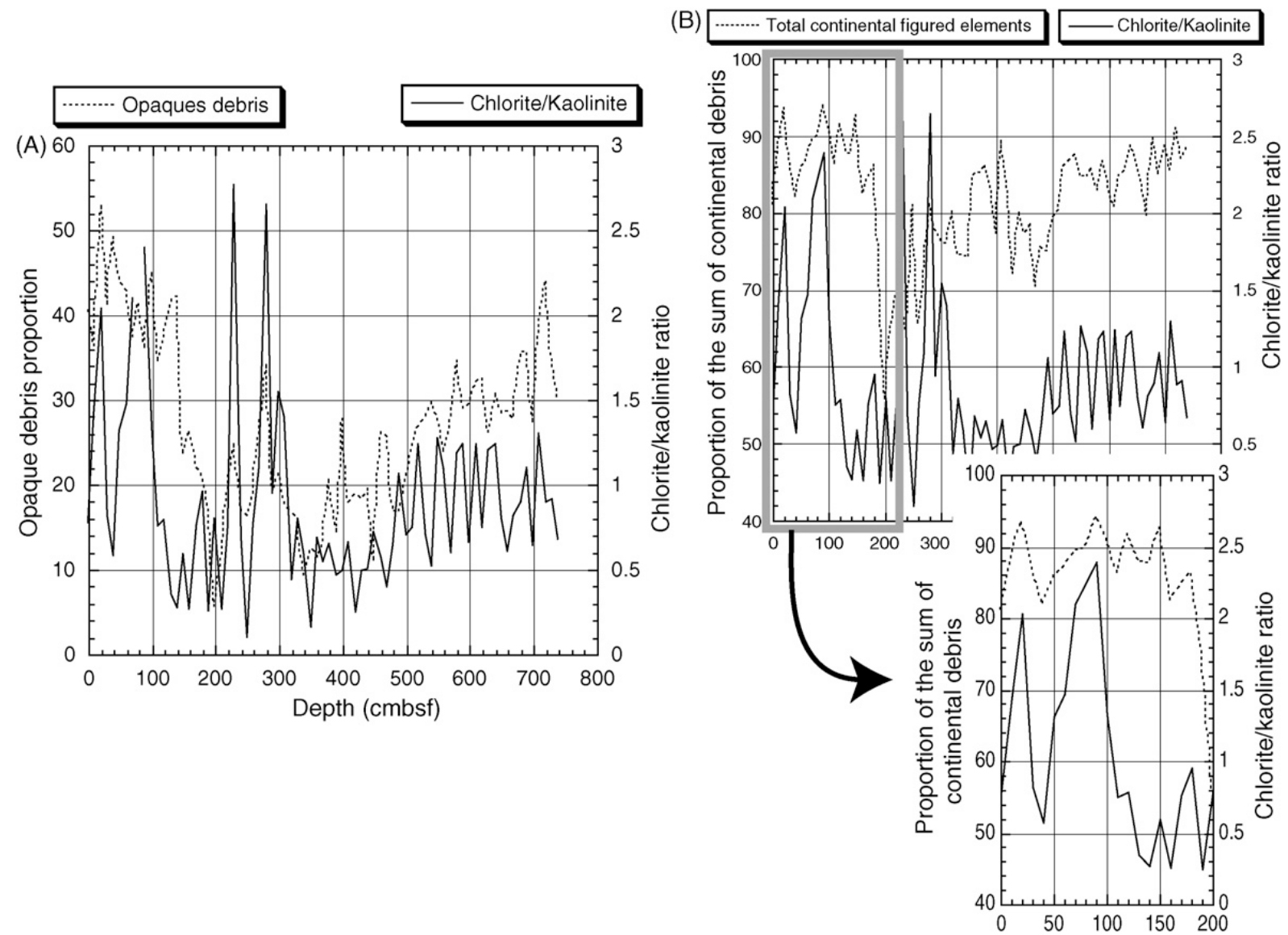

Fig. 5. Stratigraphic distribution of the values of the chlorite/kaolinite ratio, compared to that of opaque organic debris (A) and the sum of the terrigenous figured elements (B).

Fig. 5. Distribution stratigraphique des valeurs du rapport chlorite/kaolinite, comparé à celui des débris organiques opaques (A) ou de la somme des débris organiques continentaux (B). 